\title{
Characteristics and Seasonal Variation of Carbonaceous and Water Soluble Organic Components in the Aerosols over East India
}

\author{
BASANT SHUBHANKAR $^{1 *}$, BALRAM AMBADE ${ }^{1}$, \\ SUDHIR KUMAR SINGH ${ }^{2}$ and SARITA GAJBHIYE MESHRAM ${ }^{3}$
}

'Department of Chemistry, National Institute of Technology, Jamshedpur-831014, Jharkhand, India.

${ }^{2} \mathrm{~K}$. Banerjee Centre of Atmospheric and Ocean Studies, IIDS, University of Allahabad, Allahabad-211002 India.

${ }^{3}$ Department of Water Resources Development and Management, IIT, Roorkee, Uttarakhand, India.

Corresponding author E-mail: bambade.chem@ nitjsr.ac.in

http://dx.doi.org/10.13005/ojc/320160

(Received: December 17, 2015; Accepted: March 09, 2016)

\begin{abstract}
The present investigation intends to measurement of $\mathrm{PM}_{25}$ and $\mathrm{PM}_{10}$ samples from agricultural (AG) and an Adityapur industrial (AI) site of East India to better characterize the carbonecous and water-soluble organic carbon (WSOC). The current study aimed (a) to determine variation ratio of $\mathrm{OC} /$ $\mathrm{PM}, \mathrm{EC} / \mathrm{PM}, \mathrm{WSOC} / \mathrm{EC}, \mathrm{OC} / \mathrm{EC}$ in the study area (b) assess and quantity the Correlation between $O C$ and EC, WSOC and OC, WSOC and PM, WSOC and EC of AG and Al site (c) Analyse the abundance pattern, at $A G$ site indicating dominant contribution from biomass burning sources (woodfuel and agriculture waste) and in Al site sharp contrast influenced by emissions from coal-fired industries. The $\mathrm{OC}_{10} / \mathrm{EC}_{10}, \mathrm{OC}_{2.5} / \mathrm{EC}_{2.5} \mathrm{OC}_{10} / \mathrm{PM}_{10}, \mathrm{OC}_{2.5} / \mathrm{PM}_{2.5}, \mathrm{EC}_{10} / \mathrm{PM}_{10}, \mathrm{EC}_{2.5} / \mathrm{PM}_{2.5}$ ratios at the $\mathrm{Al}$ and AG sampling sites varied from (min-max (average)) are 2.8 - 8.3 (4.9), 4.2 - 7.6 (5.5), $0.17-0.19$ (0.17), $0.14-0.20(0.17), 0.03-0.06(0.04), 0.02-0.04(0.03)$ and $3.3-8.3(4.9), 3.03-8.8(3.9)$, 0.62 - 0.98 (0.78), 0.09 - $0.12(0.09), 0.07-0.23(0.17), 0.01-0.04(0.02)$ respectively. Total carbon (TC) was calculated as OC+EC. The comprehensive data set on EC, OC and WSOC/OC ratios from Eastern India is crucial to systematise the baseline data for future predictions of carbonaceous aerosol studies for atmospheric scattering and absorption of solar radiation on a regional scale.
\end{abstract}

Key word: OC, EC, WSOC, AG site, Al site.

\section{INTRODUCTION}

In India from the ancient few decades there have been an intense growth in transportation, industrial activities and large-scale advanced farming as a result of which, there is huge emissions of carbonaceous aerosols in India, and the consequence of which provide us unique platform for research in atmospheric chemistry. The particulate matter (PM) composition has become one of the essential and 
ultimate topics in the field of atmospheric science and one of such area is carbonaceous fraction since this component makes up about the half of the particulate mass concentration ${ }^{1}$. One of the key issues in the study of carbonaceous aerosol particularly water soluble organic carbon (WSOC), is the identifying the possible source region which pose a great hazard to air quality, atmospheric radiative budget ${ }^{2}$, human health ${ }^{3}$, worldwide and regional climate change, and visibility dilapidation ${ }^{4}$ Nearly $33 \%$ of atmospheric aerosol mass loading constitutes with WSOC which include forest area, urban ${ }^{5-6}$, rural and marine atmospheres ${ }^{7}$.

WSOC aerosols mainly poised of elemental carbon (EC) and organic carbon (OC) and the involvement of these are approximately $(\sim 10-$ $70 \%$ ) to the in $\mathrm{PM}_{2.5}$ level. A global catalogue of carbonaceous aerosols ${ }^{8-9}$. According to Streets ${ }^{10}$ reported that biomass burning is the major source of $O C$ and $E C$ in the atmosphere globally and next major source of OC and EC emissions in Asia. WSOC may be originated from various sources such as primary emissions like industry, wood or oil combustion, sea spray, or mineral (soil) dust as well as secondary aerosols.

EC is a primary pollutant ${ }^{11}$ derived exclusively from the incomplete combustion from carbon-contained compound, such as burning of fossil fuel $\mathrm{I}^{12}$ and biomass burning ${ }^{13}$. As a result of incomplete burning the emitted EC form a basic constituent of "soot" particles, and the nature of which is highly refractory and its chemical structure is somewhat similar to graphitic carbon. The fundamental behaviour of EC is that it does not take part directly in the chemical reactions and is considered to be inert, but wherever it gets a chance, it may provide an active surface for heterogeneous reactions ${ }^{14}$. EC has considered showing dynamic role in earth climate change because it causes positive radiative forcing and possesses a strong capability of absorbing solar radiation. OC composition is of vary nature it represents a mixture of hundreds of organic compounds, some of which act as carcinogenic and/ or mutagenic, such as dibenzofurans, polychlorinated dibenzo-p-dioxins and polycyclic aromatic hydrocarbons ${ }^{15}$. OC can be mainly accredited to primary organic carbon released from burning and primary biogenic source, and secondary organic carbon made by both photochemical oxidation of volatile precursors and successive gas-to-particle conversion developments ${ }^{16}$.

The adverse effects of WSOC have also attracted extensive attention of the public and government on human health in recent years. Over the past decades, number of health effects studies have reported consistent connotations amid exposure to particulate matter (PM) and a variety of adverse severe/chronic health effects risk of adverse birth outcomes ${ }^{17}$, respiratory outcomes ${ }^{18}$, and cardiovascular diseases ${ }^{19}$.

Unfortunately, present understanding of WSOC ( $\mathrm{PM}_{2.5}$ and $\mathrm{PM}_{10}$ ), including its sources (both primary and secondary), atmospheric procedure (both physical and chemical), and effects on (both human and the atmosphere), is still limited for the study area, Jamshedpur Jharkhand.

The study reported in this manuscript aims to assess the abundances of carbonaceous species (EC, OC and WSOC) in the atmospheric outflow from the Jamshedpur. The purpose of this study we have used a mass closure approach to estimate the conversion factor of $\mathrm{OC}$ to organic matter (OM or organic mass) in the atmospheric outflow. In addition, chemical characterization and Seasonal atmospheric outflow were also intended.

\section{MATERIALS AND METHODS}

\section{Study sites}

Jamshedpur $\left(22.47^{\circ} \mathrm{N}\right.$ and $\left.86.12^{\circ} \mathrm{E}\right)$ is situated in the southern end of the state of Jharkhand and is bordered by the states of Orissa to the south and to the west by West Bengal. It is primarily located in a hilly region of Chhotanagpur plateau and is surrounded by the Dalma Hills which is running from west to east and covered with dense forests. According to 2011 census more than $1,337,131$ inhabitants lives in an area of about 150 $\mathrm{km}^{2}$ and is the second largest town in Jharkhand state. It is the first planned industrial town of India, established by Jamshedji Tata. Jamshedpur is a major industrial hub of East India. It houses companies like Tata Steel, Tata Power, Lafarge Cement, Telcon, Tata Motors, Praxair, TCE, TCS, Timken, TRF, BOC Gases, Tinplate etc. surrounded by more than 1,200 
small and medium scale industries. The sampling sites location has been shown in the Fig. 1.

\section{Adityapur industrial (Al) Site}

Most of the smaller and middle scale companies are located in the 'Adityapur Industrial Estate' (33,970 acres, 53 sq. mile) which has been a Asia's largest Industrial hub. Approximate 1,200 industries are located here and about 250 are in pipeline. There are about 20 Larger Scale Industries located like Adhunik Group, TGS, Usha Martin, RSB etc.

\section{Agriculture (AG) Site}

Chandil is located at $\left(22.97^{\circ} \mathrm{N}\right.$ and $\left.86.05^{\circ} \mathrm{E}\right)$. It has an average elevation of 246 metres (807 feet) and is nearly $30 \mathrm{kms}$ from site Al.The natural scenery in and around Chandil is unique and enchanting. It is surrounded by agriculture land, green mountains. The Dalma mountains which are the crown of Chandil is the safe for many wild animals like Elephants, Deer, Wild Pigs, Sambhar and many species of birds and snakes. Dalma Wild

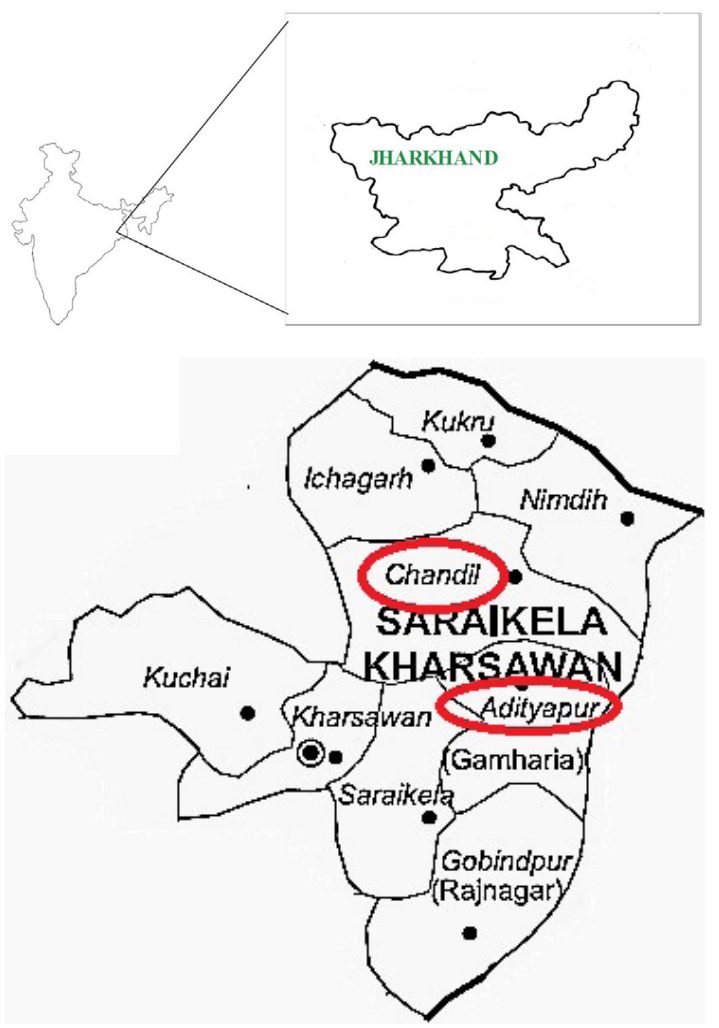

Fig. 1: Location of sampling sites
Life Sanctuary (DWLS) is famous for Elephants and Deer. The main occupation of the people near this sampling site is farming, fishing, cattle rearing etc. People near to this sampling site uses wood, cow dung for burning purpose. Biomass burning of crops residue is used extensively by the habitant of this region.

\section{Metrological parameter}

The climatic pattern is of typical tropical monsoon type with the year subdivided into three major seasons as: summer, monsoon and winter. We fixed organized sampling in the month of AprilMay and December -January as shown in Fig 2. During April - May the mean maximum temperature is $35^{\circ} \mathrm{C}$ whereas the mean minimum temperature is $28^{\circ} \mathrm{C}$ and During December - January the mean maximum temperature is $22^{\circ} \mathrm{C}$ whereas the mean minimum temperature were $17^{\circ} \mathrm{C}$. The maximum humidity, observed during the monsoon season, has mean value of $85 \%$. The minimum mean humidity in summer (April-May) is $26 \%$ and winter December -January is $63 \%$. The wind speed and visibility during the sampling period was in the range of $0-6 \mathrm{~km} / \mathrm{h}$ and $2-4 \mathrm{~km}$ respectively. The solar radiation flux during the sampling period April-May was in the range of $21.19-24.12$ watt $/ \mathrm{m}^{2}$ and during the month of December-January is in range of $12.21-15.76$ watt $/ \mathrm{m}^{2}$. All meterological data are acquired from the nearest meteorological office of IMD (Indian Meteorological Department).

\section{Sampling}

Ambient 24-h integrated $\mathrm{PM}_{10}$ and $\mathrm{PM}_{2.5}$ (particulate matter less than 2.5 and $10 \mu \mathrm{m}$ aerodynamic diameters, respectively) samples were collected with a high volume (Hi-Vol) sampler (Thermo Scientific, MA, USA) at both site AI and AG. The sampling sites are located in urban-industrial and rural which is in the radius of $20 \mathrm{~km}$ from the NIT Jamshedpur, Jharkhand. Samplers were set up at <"10-15 m above ground level at both sites. The sampling was carried in the month of April, May, Dec (2014) and Jan (2015) dated $7^{\text {th }}, 8^{\text {th }}$ and $9^{\text {th }}$ of above mentioned month shown in Fig 2. A total of 50 samples were collected. Pre-baked Quartz filters (8×10 in, 2500 QAT-UP; Pall Corporation, NY, USA) was used for the sampling. After sampling, the filters were swathed in aluminium foil and kept in freezer until analyses. 


\section{$\mathrm{EC}$ and $\mathrm{OC}$ Analysis}

$\mathrm{PM}_{1.0}$ and $\mathrm{PM}_{2.5}$ Samples were analysed for EC and OC using the Thermo- Optical Transmission (TOT) method on a Sunset Lab analyser ${ }^{20-21}$. In this method we use different temperatures to oxidised EC and OC. The chief task of the optical module of the analyzer is an alteration for the pyrolysis of organic carbon. The eight fractions $\mathrm{OC}_{1}, \mathrm{OC}_{2}, \mathrm{OC}_{3}$, $\mathrm{OC}_{4}, \mathrm{EC}_{1}, \mathrm{EC}_{2}, \mathrm{EC}_{3}$ and PC (Pyrolyzed Carbon) are reported. The IMPROVE protocol defines OC as $\left(\mathrm{OC}_{1}+\mathrm{OC}_{2}+\mathrm{OC}_{3}+\mathrm{OC}_{4}+\mathrm{PC}\right)$ and $\mathrm{EC}$ as $\left(\mathrm{EC}_{1}+\right.$ $\mathrm{EC}_{2}+\mathrm{EC}_{3}-\mathrm{PC}$ ). For $\mathrm{OC}$ analysis a filter punch is submitted to volatilization at $250,500,650^{\circ} \mathrm{C}$ for $60 \mathrm{~s}$ and $870^{\circ} \mathrm{C}$ for $90 \mathrm{~s}$ in a $100 \%$ helium atmosphere, and for $\mathrm{EC}$ it is heated at $600,700,850^{\circ} \mathrm{C}$ for $45 \mathrm{~s}$ and $900{ }^{\circ} \mathrm{C}$ for 120 s in $2 \%$ oxygen and $98 \%$ helium atmosphere. The analysis is based on liberating carbon compounds at different temperatures. At temperature $900^{\circ} \mathrm{C}$ the sample boat having a punch of $0.5 \mathrm{~cm}^{2}$ area is passed through the oxygenator containing heated $\mathrm{MnO}_{2}$. The concentration of $\mathrm{CH}_{4}$ is detected by using a Flame Ionization Detector (FID) at $125^{\circ} \mathrm{C}$. The initial transmittance through the filter, measured using $678 \mathrm{~nm}$ laser source is used to define the split-point between $O C$ and $E C$ and to correct for the Pyrolyzed carbon formed during initial charring of $\mathrm{OC}$ in a passive atmosphere. At the end of every analytical run, a fixed volume of methane $\left(5 \% \mathrm{CH}_{4}+95 \% \mathrm{He}\right.$, $\left.\mathrm{Vol} / \mathrm{Vol}\right)$ is injected as an internal standard to assess the performance of FID.The overall analytical uncertainty in the measurement is calculated by summing up the absolute and relative uncertainties. Absolute uncertainty in measurement of OC (or EC) is $0.2 \mu \mathrm{g} \mathrm{cm}^{22}$ and TC is $0.3 \mu \mathrm{g} \mathrm{cm}^{\prime 2}$ while the relative uncertainty of the measured concentration is $5 \%$.

\section{WSOC analysis}

Before analysis one-fourth filters $\left(4105 \mathrm{~cm}^{2}\right.$ areas) was soaked Milli- $Q$ water (7 ml for low volume filters and $20 \mathrm{ml}$ for high volume filters, resistivity: $18.2 \mathrm{MU} \mathrm{cm}$ ) and subjected to ultrasonicated for $41 / 2 \mathrm{~h}$ for extraction of the WSOC. The resulting water-extract were filtered using PTFE membrane single use syringe filters (Sartorius Minisart SRP 15) and transferred to a pre-cleaned glass vial and was

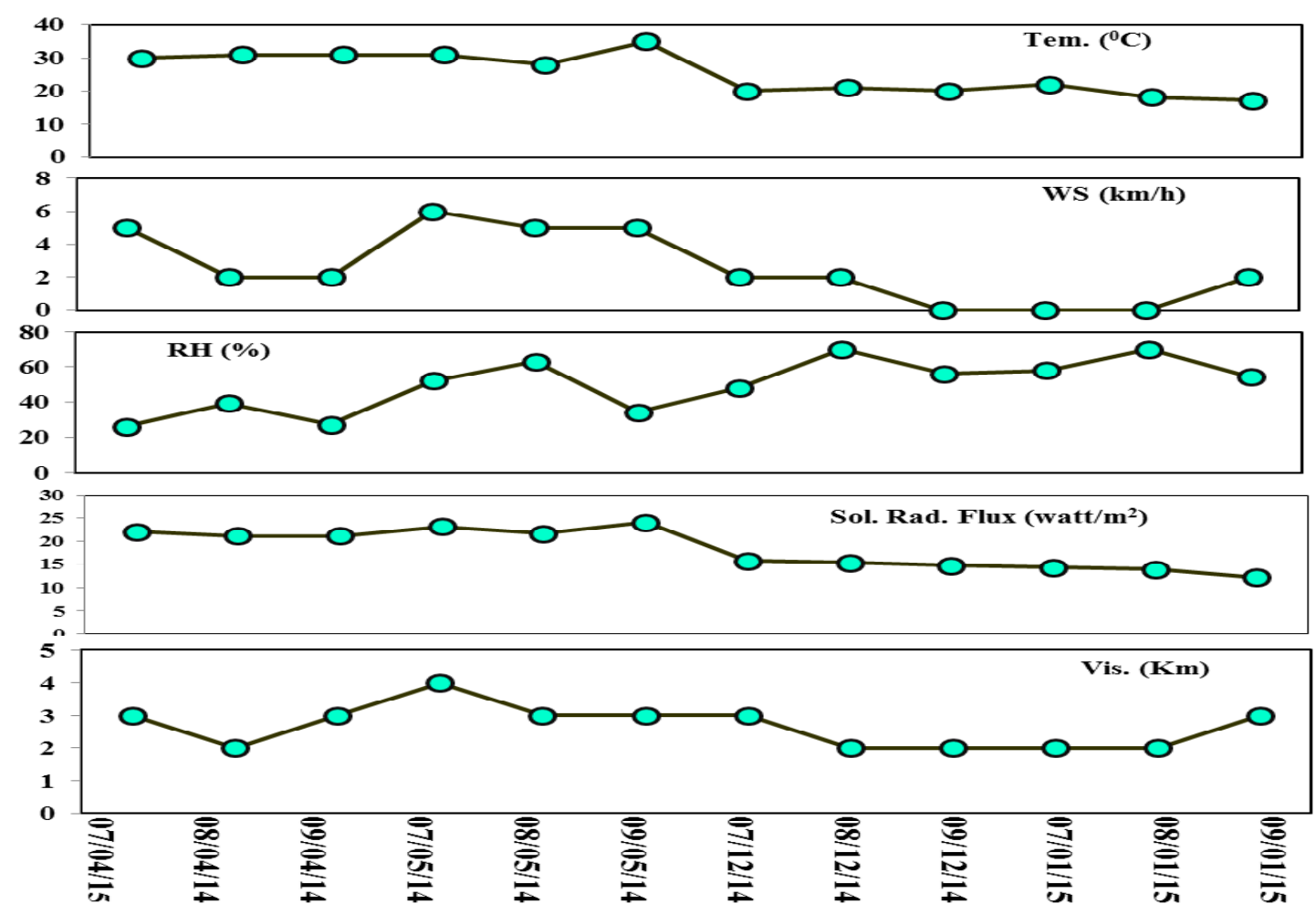

Fig. 2: Day to day variability of metrological conditions (a) Temperature (b) Wind Speed (WS) (c) Relative Humidity (RH) (d) Solar Radiative Flux and (e) Visibility at two Sampling Sites 
analysed using a TOC liquid analyser (Shimadzu, model TC5000A). In an optimized analytical procedure, $25 \mathrm{ml}$ of water - extract is injected into the furnace crammed with platinum catalyst at a temperature of $680{ }^{\circ} \mathrm{C}$, thus the $\mathrm{CO}_{2}$ developed is measured by using a non- dispersive infrared (NDIR) detector to assess total carbon (TC) content.

\section{RESULT AND DISCUSSION}

\section{Mass concentration of PM}

A total of $50 \mathrm{PM}_{2.5}$ and $\mathrm{PM}_{10}$ samples (including field blanks) was collected for this study. Mass concentration of $\mathrm{PM}_{10}$ has varied from 191 to $312 \mu \mathrm{g} / \mathrm{m}^{3}$ with an averaged value of $(249.1 \mu \mathrm{g} /$
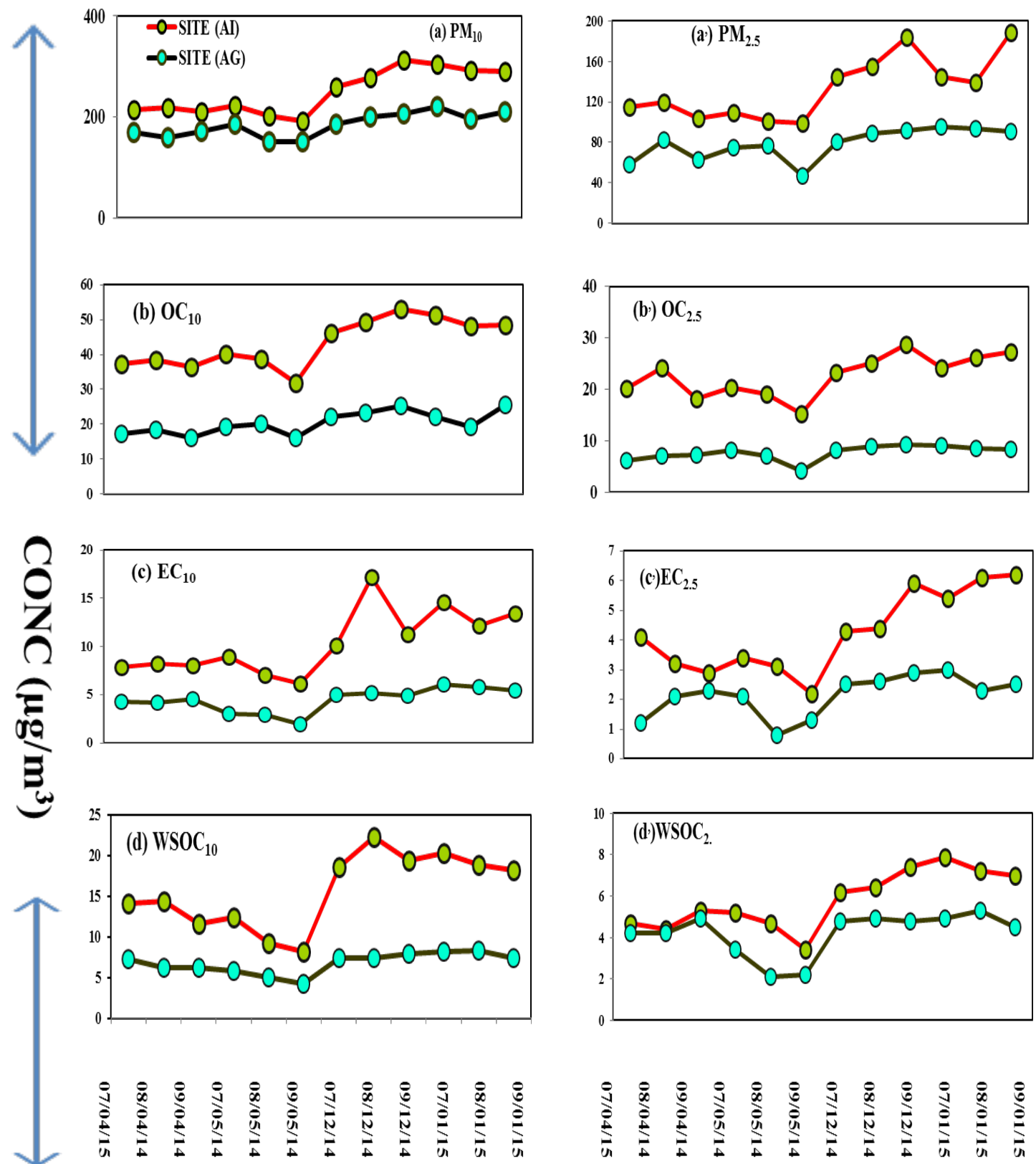

Fig. 3: Temporal and Spatial variability of (a) $\mathrm{PM}_{10}, \mathrm{PM}_{2.5}$ and the associated carbonaceous species: (b) OC (c) EC and (d) WSOC 
$\mathrm{m}^{3}$ ) at sampling site $\mathrm{Al}$, minimum value during the month of May and maximum value in the month of December Fig 3 (a). Similarly, Mass concentration of $\mathrm{PM}_{2.5}$ has varied from 99 to $189 \mu \mathrm{g} / \mathrm{m}^{3}$ with an averaged value of $(133.7 \mu \mathrm{g} / \mathrm{m} 3)$ at sampling site $\mathrm{Al}$, minimum value during the month of May and maximum value in the month of December Fig (3a). Fig. 3 shows the variation in mass concentration of $\mathrm{PM}_{10}$ and $\mathrm{PM}_{2.5}$ of both the sampling sites. Higher concentration of $\mathrm{PM}_{10}$ and $\mathrm{PM}_{2.5}$ in the month of December-January at both the sampling sites may be due to the combined effect of source strength and lower boundary layer height ${ }^{22}$. Generally during winter, the meteorology of Jamshedpur is dominated by high pressure centered over Western Dalma hill instigating enlarged atmospheric constancy, which turn and allows less general circulation engulfing extra stagnant air masses. Moreover, deficiency
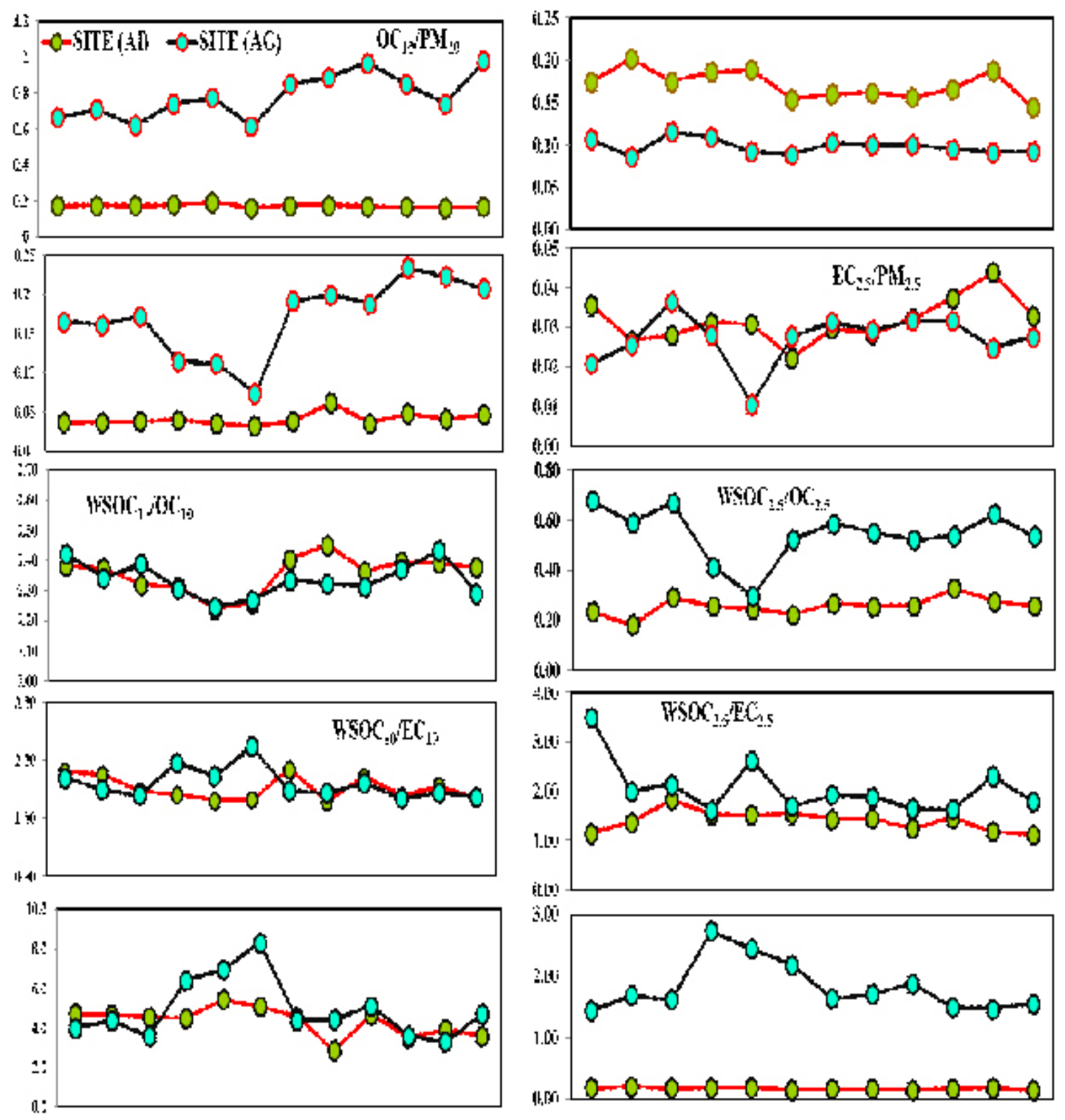

Fig. 4: Variation of (a) OC/PM, ( b)EC/PM, (c) WSOC/EC (d) OC/EC ratios during the sampling period at the given study sites 
of precipitation in the winter too may decrease the potential of wet deposition and allied cleansing mechanisms of the atmosphere.

$\mathrm{PM}_{10}$ and $\mathrm{PM}_{2.5}$ samples are analysed for OC, EC, and WSOC (Fig 3 b-d). It has been observed that average of total carbon ( $\mathrm{TC}=\mathrm{OC}+\mathrm{EC})$ concentration contribute $443 \%$ and $420 \%$ of $\mathrm{PM}_{10}$ and $\mathrm{PM}_{2.5}$ masses respectively, whereas, WSOC account for $425 \%$ and $411 \%$ of $\mathrm{PM}_{10}$ and $\mathrm{PM}_{2.5}$ masses respectively at both the sampling sites. The contribution of unidentified mass (UM), estimated by subtracting TC and WSOC concentrations from the $\mathrm{PM}_{10}$ and $\mathrm{PM}_{2.5}$ masses. The UM accounts for 4 $32 \%$ and $469 \%$, respectively, of total $\mathrm{PM}_{10}$ and $\mathrm{PM}_{2.5}$ masses. Ram and Sarin ${ }^{23}$ have also estimated $41.4 \%$ unidentified mass of $\mathrm{PM}_{10}$ at Kanpur, IGP, India whereas $42.3 \%$ and $51.5 \%$ UM of TSP at Hissar and Allahabad of IGI, India ${ }^{24}$.

\section{Spatial and temporal distributions of $O C$ and EC}

Spatial and temporal distributions of $\mathrm{OC}$ and EC are illustrated in Fig. 3(b, b', c, c'). The
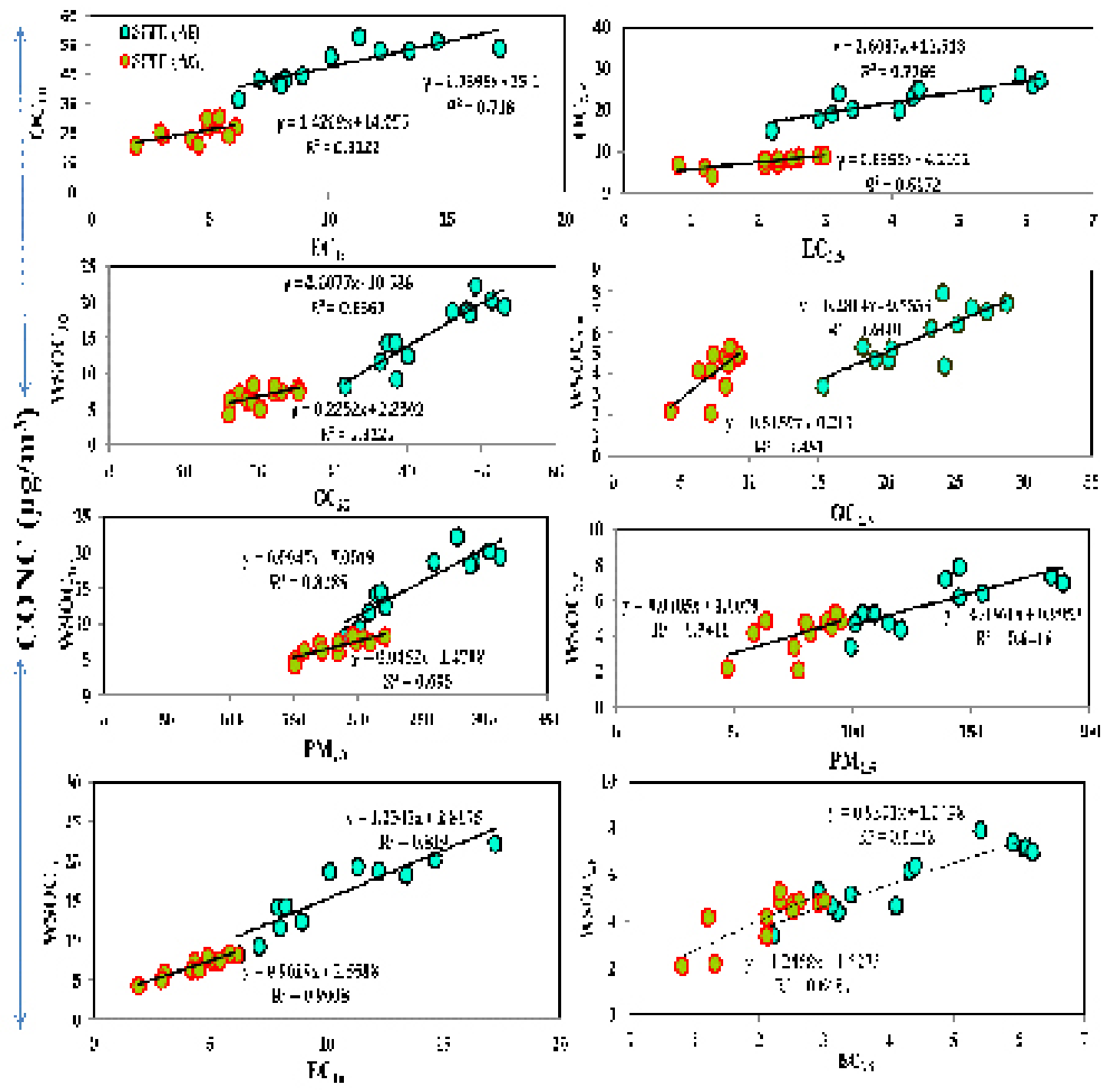

Fig. 5: Correlation between (a) OC and EC (b) WSOC and OC (c) WSOC and PM (d) WSOC and EC for the two sampling sites 
carbon concentrations can be affected by several factors.one of such factor is Dilution and it is due to enlarged mixing depths ${ }^{25}$ and particle washout on rainy days resulted in lower PM and carbon levels in the April-May. Winter time stagnation decreased the dispersion and transport of pollutants and resulted in an increase in pollution levels. $\mathrm{OC}_{10}$, $\mathrm{OC}_{2.5}$ concentrations at the $\mathrm{Al}$ and $\mathrm{AG}$ sites ranged from 31.7 to $53.1 \mu \mathrm{g} / \mathrm{m}^{3}, 15.3$ to $28.7 \mu \mathrm{g} / \mathrm{m}^{3}$ and 16.0 to $25.4 \mu \mathrm{g} / \mathrm{m}^{3}, 4.2$ to $9.2 \mu \mathrm{g} / \mathrm{m} 3$, respectively Fig 3 (b, b'), whereas the corresponding $\mathrm{EC}_{10}$ and $\mathrm{EC}_{2.5}$ ranged from 6.2 to $14.6 \mu \mathrm{g} / \mathrm{m}^{3}, 2.2$ to $6.2 \mu \mathrm{g} / \mathrm{m}^{3}$ and 0.8 to $3.0 \mu \mathrm{g} / \mathrm{m}^{3}$ at sites $\mathrm{Al}$ and $A G$ respectively Fig 3 (c, c').

Average $\mathrm{OC}_{10}$ and $\mathrm{OC}_{2.5}$ concentrations at the $\mathrm{Al}$ site where nearly 2- 4 times higher than AG site Fig 3 (b, b') and Average $\mathrm{EC}_{10}$ and $\mathrm{EC}_{2.5}$ concentrations were approx. 2-3 times higher than those at the AG site Fig 3 (c, c'). Elevated OC and $\mathrm{EC}$ concentrations at the $\mathrm{Al}$ site reflect the influence of vehicle exhaust, biomass burning, wood burning, crop residue burning along with emissions from restaurants and nearby industries. Ratios of $O C$ to EC have been used to suggest the source of carbonaceous particles ${ }^{26-27}$. Fig 4 shows that the, $\mathrm{OC}_{10} / \mathrm{EC}_{10}, \mathrm{OC}_{2.5} / \mathrm{EC}_{2.5}, \mathrm{OC}_{10} / \mathrm{PM}_{10}, \mathrm{OC}_{2.5} / \mathrm{PM}_{2.5}, \mathrm{EC}_{10} /$ $\mathrm{PM}_{10} \mathrm{EC}_{2.5} / \mathrm{PM}_{2.2}$ ratios at the $\mathrm{Al}$ and $\mathrm{AG}$ sampling sites varied from 2.8 - 8.3 (avg 4.9), 4.2 - 7.6 (avg 5.5), 0.17 -0.19 (avg 0.17), 0.14 - 0.20 (avg 0.17), $0.03-0.06$ (avg 0.04), $0.02-0.04$ (avg 0.03) and 3.3 - 8.3 (avg 4.9), 3.03 - 8.8 (avg 3.9), 0.62 - 0.98 (avg 0.78), $0.09-0.12$ (avg 0.09), $0.07-0.23$ (avg 0.17 ), $0.01-0.04$ (avg 0.02) respectively. Whereas, ${ }^{23}$ Ram and Sarin ${ }^{23}$ reported the same in the range of

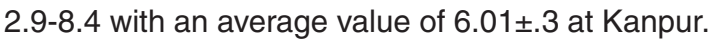
Low OC/PM and EC/PM ratios are primarily due to the elevated $\mathrm{PM}$ concentrations at the $\mathrm{Al}$ and $\mathrm{AG}$ is sampling sites, implying direct emissions from anthropogenic sources. Elevated OC/EC ratios at the local site suggested the transport of old aerosol it may have included secondary organic aerosol (SOA). However, the OC/EC ratios over Jamshedpur and some of the urban locations mentioned in the Table 1 are relatively higher than those (average $:<4.0$ ), Such difference in the OC /EC ratio for two dissimilar states might be due to alterations in discharge causes of carbonaceous aerosols ${ }^{23}$.
Fig. 5 shows the scatter plot between $\mathrm{OC}_{10}$ and $\mathrm{EC}_{10}$ during the study period $\left(\mathrm{r}^{2}=0.71\right.$; and $\left.r^{2}=0.31\right)$ at sites $A I$ and $A G$ respectively. Similarly between $\mathrm{OC}_{2.5}$ and $\mathrm{EC}_{2.5}$ during the study period $\left(r^{2}=0.77\right.$; and $\left.r^{2}=0.61\right)$ at sites $A I$ and $A G$ respectively. A significant correlation between $O C$ and EC is usually revealing of their common sources like vehicular traffic ${ }^{12}$. In contrast, a poor correlation between $O C$ and EC specifies the formation of SOA under approving circumstances for the gas to particle alteration of VOCs through a photochemical reaction in the atmosphere. Overall, a positive linear trend is observed between OC and EC for an Al and AG sites of Jamshedpur.

\section{WSOC Concentration}

The water-soluble fraction of OC (i.e., WSOC) frequently consists of larger than 30\% of $\mathrm{PM}_{2.5}$ or $\mathrm{PM}_{10} \mathrm{OC}$, often being related to polar compounds and correlated with SOA pattern ${ }^{28}$. WSOC has the potential to modify the hygroscopic properties of particles, including PM size and cloud condensation nuclei activities ${ }^{29}$. More than $80 \%$ of all WSOC were in $\mathrm{PM}_{2.5}$ at both sites (means of $84 \%$ at $\mathrm{Al}$ and $82 \%$ at $A G$ ), and the ratios were relatively stable during our observation period. The $\mathrm{PM}_{10}$ and $\mathrm{PM}_{2.5}$ concentrations of $\mathrm{WSOC}$ at $\mathrm{Al}$ and $\mathrm{AG}$ sites ranged from $8.2-22.3 \mu \mathrm{g} / \mathrm{m}^{3}\left(\operatorname{avg} 15.68 \mu \mathrm{g} / \mathrm{m}^{3}\right), 4.3$ - $8.4 \mu \mathrm{g} / \mathrm{m}^{3}\left(\operatorname{avg} 6.8 \mu \mathrm{g} / \mathrm{m}^{3}\right), 3.4-7.9 \mu \mathrm{g} / \mathrm{m}^{3}$ (avg 5.8), $2.1-5.3 \mu \mathrm{g} / \mathrm{m}^{3}$ (avg 4.1) respectively Fig 3(d, d'). The concentrations of $\mathrm{WSOC}_{10}$ and $\mathrm{WSOC}_{2.5}$ were higher in December and January and low in the month of April and May.

Fig. 5 shows the relationships between WSOC $_{10}$ and $\mathrm{WSOC}_{2.5}$ with (a) $\mathrm{OC}_{10}$ and $\mathrm{OC}_{2.5}$, (b) $\mathrm{PM}_{10}$ and $\mathrm{PM}_{2.5}$ and (c) $\mathrm{EC}_{10}$ and $\mathrm{EC}_{2.5}$ at $\mathrm{Al}$ and $\mathrm{AG}$ sites. The regression lines between $\mathrm{WSOC}_{10}\left(\mathrm{r}^{2}-0.82\right)$ and $\mathrm{PM}_{10}\left(\mathrm{r}^{2}-0.6\right)$ were almost the same for $\mathrm{WSOC}_{2.5}$ $\left(r^{2}-0.82\right.$ and $\mathrm{EC}_{2.5}\left(\mathrm{r}^{2}-0.64\right)$ at $\mathrm{Al}$ and $\mathrm{AG}$ respectively. The regression lines for $\mathrm{WSOC}_{10}$ and $\mathrm{OC}_{10}$, and $\mathrm{WSOC}_{2.5}$ and $\mathrm{OC}_{2.5}$ however, were quite different. We also examined the $\mathrm{WSOC}_{10} / \mathrm{OC}_{10}, \mathrm{WSOC}_{2.5} / \mathrm{OC}_{2.5}$, $\mathrm{WSOC}_{10} / \mathrm{EC}_{10} ; \mathrm{WSOC}_{2.5} / \mathrm{EC}_{2.5}$ ratio in Fig. 4 for $\mathrm{Al}$ and AG sampling sites. The WSOC/OC and WSOC/EC ratios for $P M_{10}$ and $P M_{2.5}$ ratios at site $A l$ ranged from 0.24 to $0.45 \mu \mathrm{g} / \mathrm{m}^{3}$ (avg $0.35 \mu \mathrm{g} / \mathrm{m}^{3}$ ), 1.30 to $1.85 \mu \mathrm{g} /$ $\mathrm{m}^{3}$ (avg $1.51 \mu \mathrm{g} / \mathrm{m}^{3}$ ), 0.18 to $0.29 \mu \mathrm{g} / \mathrm{m}^{3}$ (avg $0.25 \mu \mathrm{g} /$ $\mathrm{m}^{3}$ ), 1.34 to $1.83 \mu \mathrm{g} / \mathrm{m}^{3}$ (avg $1.4 \mu \mathrm{g} / \mathrm{m}^{3}$ ) respectively. 
Again for the site AG the WSOC/OC and WSOC/EC ratios for $\mathrm{PM}_{10}$ and $\mathrm{PM}_{2.5}$ ratios ranged from 0.25 to $0.44 \mu \mathrm{g} / \mathrm{m}^{3}$ (avg $0.33 \mu \mathrm{g} / \mathrm{m}^{3}$ ), 1.34 to $2.24 \mu \mathrm{g} / \mathrm{m}^{3}$ (avg $1.60 \mu \mathrm{g} / \mathrm{m}^{3}$ ), 0.30 to $0.68 \mu \mathrm{g} / \mathrm{m}^{3}$ (avg $0.54 \mu \mathrm{g} / \mathrm{m}^{3}$ ), 1.62 to $3.50 \mu \mathrm{g} / \mathrm{m}^{3}$ (avg $2.06 \mu \mathrm{g} / \mathrm{m}^{3}$ ) respectively Fig (4). The ratios did not vary considerably by season, but they did tend to increase slightly in April and May and decrease in December and January. Ambade ${ }^{1}$ accounted WSOC/OC ratios of 0.61 in August, 0.64 in June, and 0.31 in October at an urban site, and WSOC/OC ratios boost under high photochemical vigorous state. Miyazaki ${ }^{30}$ quoted WSOC/OC ratios of 0.35 in summer and 0.19 in winter 2004 in Tokyo. In this study, the WSOC/OC ratio also increased in April-May, when photochemical reactions are most active.

The WSOC/EC ratios for $\mathrm{PM}_{10}$ and $\mathrm{PM}_{2.5}$ were much higher on AG site. The average WSOC/ EC ratio $\mathrm{PM}_{10}$ and $\mathrm{PM}_{2.5} 1.60$ and 2.06. The difference in the WSOC/EC and WSOC/OC ratios between sites $A G$ and $A l$ indicates that the chemical components and EC characteristics were different; the higher WSOC/EC ratio suggested that the EC at was more oxidized in the atmosphere. This disparity between the two sites could be caused by disparities in primary emissions and secondary formation among the sites. Primary EC is predominantly water-insoluble ${ }^{30}$, and there are primary EC sources (e.g., vehicles) in site $\mathrm{Al}$, whereas there are very few sources of primary EC at site AG. Conversely, secondary formation is probably promoted during the transport of pollutants to site AG. Therefore, the WSOC ratios fraction at site $A G$ was higher than that at site Al.

\section{Comparison of OC and EC with other Asian cities}

Table 1 compares WSOC, OC, and EC concentrations in $\mathrm{PM}_{2.5}$ and $\mathrm{PM}_{10}$ from 11 cities across the world. $\mathrm{EC}_{10}$ concentration of study site $\mathrm{Al}$ ranked the highest. The concentration of WSOC, EC, and OC at Kanpur ${ }^{23}$ is 2-5 times more than present study sites; this may be due to more motor vehicles and more coal use at the Kanpur. While $\mathrm{OC}_{2.5}$ concentrations at site
AG were similar toBeijing (China) ${ }^{31}$ and for Al site the concentration of $\mathrm{OC}_{2.5}$ is nearly $2-5,3$ $5,1.5,1.5,4.5,1.5,1.5$ times than Hong Kong ${ }^{32}$, Thessaloniki (Greece) ${ }^{33}$, PRDR(China) ${ }^{34}$, Shanghai $(\text { China })^{31}$, Lanzhou(China), Guangzhou(China) $)^{31}$, respectively. $\mathrm{EC}_{2.5}$ concentrations at site $\mathrm{Al}$ were similar in Hong Kong ${ }^{32}$, Thessaloniki (Greece) ${ }^{33}$, Beijing (China)31. WSOC W.5 $_{2.5}$ show similar behavior in Shanghai (China) ${ }^{31}$ at site $\mathrm{Al}$ and for site AG it is similar to Beijing (China) ${ }^{31}$.

\section{CONCLUSION}

The present study has demonstrated spatial and temporal variations in concentration of OC, EC, and WSOC in $\left(\mathrm{PM}_{10}+\mathrm{PM}_{2.5}\right)$ level at two inland locations on the Jamshedpur during AprilMay 2014 and January 2104 - December 2015 respectively.

- $\quad$ Average $\mathrm{OC}_{10}$ and $\mathrm{OC}_{2.5}$ concentrations during the sampling period were $43.2 \mu \mathrm{gm}^{\prime 3}$ and 22.6 $\mu \mathrm{g} / \mathrm{m}^{3}$ at site AT and $20.3 \mu \mathrm{g} / \mathrm{m}^{3}$ and $7.7 \mu \mathrm{g} / \mathrm{m}^{3}$ at site $A G$, respectively; EC concentrations were $10.4 \mu \mathrm{g} /$ $\mathrm{m}^{3}, 4.2 \mu \mathrm{g} / \mathrm{m}^{3}$ and $4.4 \mu \mathrm{g} / \mathrm{m}^{3}, 2.1 \mu \mathrm{g} / \mathrm{m}^{3}$, respectively; This indicates that carbonaceous aerosol is the dominant component in the Al sampling site.

- $\quad$ All of the $\left(\mathrm{PM}_{10}\right.$ and $\left.\mathrm{PM}_{2.5}\right)$ OC/EC ratios exceeded 4.0, and average OC/EC ratios were 4.3 and 5.5 at site $A l$ and 4.9 and 3.9 at $A G$ site. Elevated OC/EC ratios were found during heating seasons with increased primary emissions, such as residential coal combustion, nearby vehicle emissions. OC/EC ratios were higher owing to the formation of SOA during transport.

- $\quad\left(\mathrm{PM}_{10}\right.$ and $\left.\mathrm{PM}_{2.5}\right)$ WSOC concentrations were $15.68 \mu \mathrm{g} / \mathrm{m}^{3}, 5.8 \mu \mathrm{g} / \mathrm{m}^{3}$ and $6.8 \mu \mathrm{g} / \mathrm{m}^{3}, 4.1 \mu \mathrm{g} /$ $\mathrm{m}^{3}$ at $\mathrm{AI}$ and $\mathrm{AG}$ sampling sites respectively. WSOC between an AT/AG pair indicated that on average AT WSOC was $49 \%$ higher than AG levels during the sampling period. The AT excess WSOC was clearly associated with local anthropogenic emissions since the WSOC enhancement was linked to $C O$ and NOx. We also inferred that WSOC was produced by photochemical reaction and was caused by the combustion of both fuel and biomass.

\section{REFERENCES}

1. Ambade, B. Lap-Lambert Academic Publishing, Germany. 2012, ISBN: 978-3-
659-30271-8.

2. Malm, W.C.; Day, D.E. Atmos. Environ. 2000, 
34, 3373-3391.

3. Dreher, K.L. Inhalation Tox. 2000, 12 (supp 3), 45-57.

4. IPCC. Cambridge Univ. Press. New York, 2007.

5. Castro, L.M.; Pio, C.A,; Harrison, R.M.; Smith, D.J.T. Atmos. Environ.1999, 33, 2771-2781.

6. Andrews, E.; Saxena, P.; Musarra, S.; Hildemann, L.M.; Koutrakis, P.; McMurry, P.H.; Olmez, I.; White, W.H. J. Air Waste Manage. Assoc. 2000, 50, 648- 664.

7. Ambade, B.; Ghosh, S. Nat. Hazard. 2013, 69, 589-598.

8. Bond, T.C.; Street, D.G.; Yarber, K.F.; Nelson, S.M.; Woo, J.H.; Klimont, Z. J. Geophys. Res. 2004, 109, D14203.

9. Wonaschutz, A.; Hersey, SP.; Sorooshian, A.; Craven, J.S.; Metcalf, A.R.; Flagan, R.C.; Seinfeld, JH. Atmos. Chem. Phys. 2011, 11, 8257-8270.

10. Streets, D.G.; Yarber, K.F.; Woo, J.H.; Carmichael, G.R. Glob. Biogeochem. Cycles. 2003, 17.

11. Seinfeld, J.H.; Pandis, S.N. Wiley., New York. 1998

12. Salma, I.; Chi, X.; Maenhaut, W. Atmos. Environ. 2004, 38, 27-36.

13. Hu, W.W.; Hu, M.; Deng, Z.Q.; Xiao, R.; Kondo, Y.; Takegawa, N. Atmos. Chem. Phys. 2012, 12, 1811-22.

14. Ambade, B. Urban Climate. 2014, 9, 155165.

15. Feng, Y.; Chen, Y.; Guo, H.; Zhi, G.; Xiong, S.; Li, J.; Sheng, G.; Fu, J. Atmos. Res. 2009, 92, 434-442.

16. Vutukuru, S.; Griffin, R.J.; Dabdub, D. J. Geophys. Res. 2006, 111, D10S12.

17. Nieuwenhuijsen, M.J.; Dadvand, P.; Grellier, J.; Martine, D.; Vrijheid, M. Environ. Health. 2013, $12,6$.

18. Eisner, M.D. Thorax. 2010, 65, 229-234.

19. Brook, R.D.; Rajagopalan, S.; Pope, C.Alll.;
Brook, J.R.; Bhatnagar, A.; Diez-Roux, A.V. Circulation. 2010, 121, 2331-2378.

20. Ram, K.; Sarin, M.M.; Hegde, P. Atmos. Environ. 2008, 42, 6785-6796

21. Rengarajan, R.; Sarin, M.M.; Sudheer, A.K. J. Geophys. Res. 2007, 112, D21307.

22. Datta, A.; Saud, T.; Goel, A.; Tiwari, S.; Sharma, S.K.; Saxena, M.; Mandal, T.K. J. Atmos. Chem. 2010, 65, 127-143.

23. Ram, K.; Sarin, M.M. Atmos. Environ. 2011, 45, 460-468.

24. Ram, K, Sarin, M.M., Sudheer, A.K.; Rengarajan, R. Aeros. Air Qual. Res. 2012, 12, 359-370.

25. Sequeira, R.; Lai, K.H. Atmos. Environ. 1998, 32, 133-144.

26. Turpin, B.J.; Huntzicker, J.J. Atmos. Environ. 1995, 29, 3257-3544.

27. Chow, J.C.; Watson, J.G.; Lowenthal, D.H.; Solomon, P.A.; Magliano, K.L.; Ziman, S.D.; Richards, L.W. Aerosol Sci. Technol. 1993, 18, 105-128.

28. Rogge,W.F.; Mazurek, M.A.; Hildemann, L.M.; Cass, G.R.; Simoneit, B.R.T. Atmos. Environ. 1993, 27A, 1309-1330.

29. Shulman, M.L.; Jacobson, M.C.; Charlson, R.J.; Synovec, R. E.; Young, T.E. Geophys. Res. Lett. 1996, 23, 277-280.

30. Miyazaki, Y.; Kondo, Y.; Takegawa, N.; Komazaki, Y.; Fukuda, M.; Kawamura. J. Geophys. Res. 2006, 111.

31. Pathak, R.K.; Wang, T.; Ho, K.F.; Lee, .SC. Atmos. Environ. 2010, 45, 318 - 325.

32. Ho, K.F.; Lee, S.C.; Cao, J.J.; Li, Y.S.; Chow, J.C.; Watson, J.G.; Funk, K. Atmos. Chem. Phys. 2006, 6, 4569-4576.

33. Samara, C.; Voutsa, D.; Kouras, A.; Eleftheriadis, K.; Maggos, T.; Saraga, D.; Petrakakis, M. Environ. Sci. Pollut. Res. 2013, 21, 1769-1785.

34. Cao, J.J.; Lee, S.C.; Ho, K.F.; Zhang, X.Y.; Zou, S.C.; Fung, Kochy.; Chow, C.J.; Watson, J.G. Atoms. Environ. 2003, 37, 1451-1460. 